\title{
KEEFEKTIFAN PEMBELAJARAN KOOPERATIF BERBASIS GAMIFIKASI AKUNTANSI PADA MAHASISWA NON-AKUNTANSI
}

\section{THE EFFECTIVENESS OF ACCOUNTING GAMIFICATION BASED COOPERATIVE LEARNING ON NON-ACCOUNTING STUDENTS}

\author{
Oleh: \\ Endra Murti Sagoro \\ Staf Pengajar Jurusan Pendidikan Akuntansi Universitas Negeri Yogyakarta \\ endra_ms@uny.ac.id
}

\begin{abstract}
Abstrak
Penelitian ini bertujuan untuk menerapkan metode pembelajaran kooperatif berbasis gamifikasi akuntansi untuk meningkatkan kemampuan mahasiswa non-akuntansi dalam penyusunan laporan keuangan. Desain penelitian ini adalah Penelitian Tindakan kelas (PTK) Eksperimen dengan dua siklus. Subjek penelitian ini adalah mahasiswa Program Studi D3 Manajemen Pemasaran FE UNY. Teknik pengumpulan data menggunakan observasi, dokumentasi, catatan lapangan, dan tes. Teknik analisis data menggunakan analisis deskriptif kuantitatif dan uji beda. Hasil penelitian menunjukkan bahwa penerapan metode pembelajaran kooperatif berbasis gamifikasi akuntansi dapat meningkatkan kemampuan mahasiswa non-akuntansi dalam penyusunan laporan keuangan dibuktikan dengan peningkatan rata-rata nilai pretest dan posttest sebesar 57,17 menjadi 87,60 dan persentase pemenuhan kriteria minimal sebelum dan sesudah penerapan tindakan sebesar $17,39 \%$ dan $82,61 \%$ serta uji Paired Sample T-Test dengan nilai Sig.(2-tailed) sebesar 0,000. Penerapan metode ini juga lebih efektif jika dibandingkan metode ceramah dan latihan dibuktikan dengan uji Independent Sample T-Test dengan nilai Sig. (2-tailed) sebesar 0,029.
\end{abstract}

Kata kunci: pembelajaran kooperatif, gamifikasi akuntansi, PTK

\begin{abstract}
This research aims to implement cooperative learning methods based accounting gamification to enhance the ability of non-accounting students in the preparation of financial statements. This study design is a class action research (PTK) Experiments with two cycles. The subjects were students of D3 Marketing Management FE UNY. Data collection technique used observation, documentation, field notes, and test. Data were analyzed using descriptive quantitative analysis and test different. The results showed that the application of cooperative learning methods based accounting gamification can improve the ability of non-accounting students in the preparation of financial statements evidenced by an increase in the average value of pretest and posttest of 57.17 into 87.60 and the percentage of fulfillment of minimum criteria before and after the implementation of the action amounted to $17.39 \%$ and $82.61 \%$, and Paired Sample T-test with the Sig. (2-tailed) of 0.000. Application of this method is also more effective than a lecture and exercises proved by tests Independent Sample T-Test with the Sig. (2-tailed) of 0.029.
\end{abstract}

Keywords: cooperative learning, accounting gamification, classroom action research

\section{PENDAHULUAN}

Akuntansi merupakan proses sistematis untuk mengolah transaksi menjadi informasi keuangan yang bermanfaat bagi para penggunanya (Warsono et al. 2010). Laporan keuangan merupakan output yang dihasilkan dari proses akuntansi. Laporan keuangan digunakan sebagai salah satu 
bahan untuk pengambilan keputusan perusahaan. Laporan keuangan menghasilkan informasi yang bermanfaat bagi penggunanya, antara lain yaitu: informasi kinerja keuangan perusahaan, informasi perubahan jumlah modal pemilik dalam suatu perusahaan, informasi posisi keuangan perusahaan terkait dengan sumber dana dan jenis penggunaan dana, dan informasi pemasukan aliran kas perusahaan (Sagoro, 2015). Setiap mahasiswa sebagai calon tenaga penyusun laporan keuangan atau sebagai pemilik perusahaan harus mampu menyusun laporan keuangan secara tepat.

Kemampuan menyusun laporan keuangan diperlukan mahasiswa agar mereka mampu menghasilkan laporan keuangan yang memuat informasi keuangan secara akurat. Namun, pada kenyataanya tidak semua mahasiswa memiliki kemampuan yang memadai untuk menyusun laporan keuangan. Kemampuan mahasiswa khususnya yang tidak memiliki latar belakang pendidikan akuntansi, kemampuan mereka dalam menyusun laporan keuangan sebagian besar rendah. Hal ini terlihat pada nilai yang diperoleh mahasiswa dari luar Program Studi Pendidikan Akuntansi dan Akuntansi pada mata kuliah Akuntansi. Kemampuan dan keahlian yang dimiliki ditentukan dari tingkatan pendidikan formal yang ditempuh (Astuti, 2007). Latar belakang pendidikan yang ditempuh sebelum masuk jenjang perdosenan tinggi dapat mempengaruhi kemampuan mahasiswa.

Peningkatan kemampuan mahasiswa dalam menyusun laporan keuangan sangat dibutuhkan terutama bagi mahasiswa yang menempuh studi di Fakultas Ekonomi seperti mahasiswa jurusan Manajemen, Ekonomi, atau Administrasi Perkantoran/ Bisnis.Lulusan dari Fakultas Ekonomi UNY khususnya program studi non kependidikan juga didesain untuk terjun di perusahaan sehingga mereka membutuhkan kemampuan untuk memahami laporan keuangan. Kemampuan memahami laporan keuangan, baik penyusunan maupun analisis laporan keuangan akan membantu mereka untuk mengambil keputusan secara tepat.

Metode pembelajaran yang tepat dibutuhkan mahasiswa yang tidak memiliki latar belakang akuntansi agar kemampuan mereka dalam hal menyusun laporan keuangan dapat meningkat. Metode pembelajaran kooperatif merupakan salah satu metode yang dapat digunakan untuk meningkatkan kemampuan mahasiswa. Pembelajaran kooperatif merupakan metode pembelajaran dengan sistem pengelompokkan/ tim kecil, yaitu antara empat sampai enam orang yang mempunyai latar belakang kemampuan akademik, jenis kelamin, ras atau suku yang berbeda (Sanjaya, 2013). Pembelajaran kooperatif mengacu pada metode pembelajaran dimana siswa bekerja sama dalam kelompok kecil dan saling membantu dalam belajar (Huda, 2012). Metode pembelajaran memiliki kelebihan yang bermanfaat bagi mahasiswa, yaitu mahasiswa memiliki kemampuan dan keberanian untukmengemukakan dan membahas suatu permasalahan yang diperoleh mahasiswa dari belajar secara bekerja sama dalam kelompok (CilibertMacmilan, 1993; Karli dan Yuliariatiningsih, 2002). Kerjasama positif dalam pembelajaran diperlukan untuk meningkatkan kemampuan mahasiswa. Adanya target untuk mencapai sesuatu atau memenangkan sesuatu menjadi suatu hal positif yang dapat diterapkan dalam pembelajaran.

dalam Kerjasama untuk mencapai target menciptakan persaingan sehat di antara tim yang terlibat. Hal ini dapat meningkatkan kemampuan mahasiswa jika desain persaingan atau kompetisi yang dirancang dapat meningkatkan motivasi mahasiswa. Motivasi belajar sangat penting bagi mahasiswa (Dimyati, 2006). Peningkatan motivasi belajar melalui pembelajaran dibutuhkan untuk meningkatkan kemampuan mahasiswa. Gamifikasi akuntansi menjadi 
salah satu pendekatan yang dapat digunakan untuk meningkatkan motivasi belajar mahasiswa. Gamifikasi diterjemahkan sebagai pemanfaatan mekanika berbasis permainan, estetika, dan cara berpikir berbasis permainan untuk menggugah ketertarikan dan motivasi beraksi, mempromosikan pembelajaran, dan menyelesaikan perrmasalahan (Kapp, 2012). Gamifikasi dapat digunakan dalam pembelajaran dalam rangka untuk membuat pembelajaran lebih menarik (Moncada \& Moncada, 2014).

Metode pembelajaran yang dapat meningkatkan kemampuan melalui kerjasama tim dan motivasi dibutuhkan bagi mahasiswa untuk belajar menyusun laporan keuangan. Mahasiswa yang tidak memiliki latar belakang akuntansi membutuhkan motivasi lebih dan kerjasama tim yang positif guna meningkatkan kemampuan dalam menyusun laporan keuangan. Pembelajaran kooperatif berbasis gamifikasi akuntansi menjadi alternatif solusi bagi permasalahan rendahnya kemampuan mahasiswa. Metode ini diharapkan dapat meningkatkan kemampuan mahasiswa menyusun laporan keuangan. Namun, perlu dilakukan penerapan dan pengujian untuk mengetahui keefektifan metode pembelajaran kooperatif berbasis gamifikasi guna meningkatkan kemampuan mahasiswa dalam menyusun laporan keuangan, khususnya bagi mahasiswa di luar Prodi Pendidikan Akuntansi dan Akuntansi.

Berdasarkan uraian permasalahan yang telah dipaparkan, rumusan masalah dalam penelitian ini yaitu sebagai berikut: "Bagaimana keefektifan penerapan pembelajaran kooperatif berbasis gamifikasi akuntansi pada kompetensi untuk meningkatkan kemampuan mahasiswa nonakuntansi dalam menyusun laporan keuangan?"

Laporan keuangan merupakan hasil dari proses akuntansi yang terdiri dari Laporan Laba Rugi, Laporan Perubahan Ekuitas, Laporan Posisi Keuangan, Laporan
Aliran Kas, dan Catatan Atas Laporan Keuangan (Suwardjono, 2002; Warsono, 2009; Weygandt et al, 2012; Sagoro, 2015). Pada penelitian ini, laporan keuangan yang menjadi objek penelitian terbatas pada laporan laba rugi, laporan perubahan ekuitas, dan laporan posisi keuangan. Ketiga laporan keuangan tersebut merupakan laporan yang dapat segera disusun ketika mahasiswa telah mengerjakan neraca lajur (kertas kerja). Sebelum mahasiswa menyusun laporan keuangan, mahasiswa harus mampu menyusun neraca lajur secara tepat sehingga diharapkan pada saat penyusunan laporan keuangan tidak terjadi kesalahan. Hal ini berarti bahwa kompetensi menyusun laporan keuangan merupakan kemampuan untuk mengerjakan atau menyusun neraca lajur dan menggunakan data-data dalam neraca lajur tersebut untuk menyusun laporan laba rugi, laporan perubahan ekuitas, dan laporan posisi keuangan.

Laporan keuangan sangat penting bagi perusahaan (Reeves, 2011). Informasi yang dihasilkan laporan keuangan dapat digunakan sebagai bahan pengambilan keputusan perusahaan. Laporan keuangan digunakan untuk menilai kinerja keuangan perusahaan sehingga dapat diketahui perkembangan perusahaan. Banyaknya manfaat yang dihasilkan dari laporan keuangan, membuat perusahaan selalu membutuhkan orang yang mampu menyusun laporan keuangan secara tepat.Lulusan dari Fakultas Ekonomi diharapkan memiliki kompetensi menyusun laporan keuangan sehingga saat mereka bekerja atau memiliki usaha mereka mampu menyusun dan menganalisis laporan keuangan bagi perusahaan.

Pembelajaran akuntansi dikembangkan dengan berbagai metode dan media. Tujuannya sama yaitu meningkatkan pemahaman dan keterampilan akuntansi bagi peserta pembelajaran. Penggunaan metode pembelajaran yang tepat dapat meningkatkan kompetensi mahasiswa. Beberapa penelitian atau kajian tentang penerapan berbagai 
metode dalam pembelajaran akuntansi telah dilakukan antara lain adalah collaborative learning (Cheng, 2009; Edmond \& Tiggeman, 2009), problem based learning (DuWayne, 2012), active learning (Fowler, 2006; Brickner \& Etter, 2008; Boyas, 2008; de Araujo \& Slomski, 2013), meaningfull learning (Mass, 2005), atau team learning (Opdecam \& Everaert, 2012). Selain metode, beberapa media telah dikembangkan termasuk media berbasis permainan. Beberapa penelitian atau kajian terkait media yang digunakan dalam pembelajaran akuntansi antara lain monopoly (Albrech, 2008), snakes and ladders (Hodkiewicz, 2012), atau mnemonic device (Laing, 2010). Salah satu metode pembelajaran yang digunakan adalah pembelajaran kooperatif. Metode ini digunakan untuk menjalin kerjasama positif untuk mencapai tujuan pembelajaran.

Pembelajaran Kooperatif merupakan metode pembelajaran dengan sistem pengelompokkan/ tim kecil, yaitu antara empat sampai enam orang yang mempunyai latar belakang kemampuan akademik, jenis kelamin, ras atau suku yang berbeda (Sanjaya, 2013). Strategi ini kini menjadi perhatian dan dianjurkan oleh para ahli pendidikan untuk digunakan. Huda (2012: 32) menyatakan "Pembelajaran Kooperatif mengacu pada metode pembelajaran dimana siswa bekerja sama dalam kelompok kecil dan saling membantu dalam belajar".Pembelajaran kooperatif dalam peningkatan kompetensi menyusun laporan keuangan merupakan metode pembelajaran dimana mahasiswa dibagi dalam beberapa tim/ kelompok untuk bekerja sama dan saling membantu dalam belajar. Di samping saling membantu, kelompok-kelompok tersebut akhirnya juga akan berkompetisi untuk menjadi yang terbaik.

Metode Pembelajaran Kooperatif memiliki karakteristik yang berbeda dengan metode pembelajaran yang lain. Menurut Sanjaya (2013), karakteristik metode pembelajaran kooperatif ada 4, yaitu: 1)
Pembelajaran secara tim; 2) Didasarkan pada manajemen kooperatif; 3) Kemauan untuk bekerja sama; dan 4) Keterampilan bekerja sama. Pembelajaran kooperatif adalah pembelajaran secara tim. Tim adalah tempat untuk mencapai tujuan. Dalam pembelajaran kooperatif, setiap mahasiswa dituntut untuk saling membantu dan bekerjasama sehingga keberhasilan kelompok ditentukan oleh tim. Kelompok yang dibentuk beragam baik dari segi kemampuan akademis, jenis kelamin, dan latar belakang fakultas yang berbeda. Pembentukan kelompok beragam ini dimaksudkan agar mahasiswa saling memberi dan menerima serta bertukar pengalaman untuk mendorong keberhasilan kelompok.

Manajemen dalam pembelajaran kooperatif memiliki 4 fungsi. Fungsi pertama, perencanaan menunjukkan bahwa pembelajaran kooperatif memerlukan perencanaan yang matang agar proses pembelajaran berjalan secara efektif. Fungsi kedua, pelaksanaan menunjukkan bahwa pembelajaran kooperatif harus dilaksanakan sesuai dengan perencanaan. Fungsi ketiga, organisasi menunjukkan bahwa pembelajaran kooperatif adalah pekerjaan bersama antar setiap anggota kelompok, oleh sebab itu perlu diatur tugas dan tanggung jawab setiap anggota kelompok. Fungsi keempat, kontrol menunjukkan bahwa dalam pembelajaran kooperatif perlu ditentukan kriteria keberhasilan.

Keberhasilan Pembelajaran

Kooperatif ditentukan oleh keberhasilan secara kelompok. Setiap anggota kelompok harus diatur tugas dan tanggung jawabnya. Dalam pembelajaran kooperatif ditekankan untuk saling bekerja sama dan saling membantu. Kemauan untuk bekerja sama itu kemudian dipraktikkan melalui aktivitas dan kegiatan yang tergambarkan dalam keterampilan bekerja sama. Dengan demikian, siswa perlu didorong untuk mau dan sanggup berinteraksi dan berkomunikasi dengan anggota lain. Mahasiswa perlu dibantu mengatasi berbagai hambatan dalam 
berinteraksi dan berkomunikasi, sehingga mahasiswa dapat menyampaikan ide, mengemukakan pendapat dan memberikan kontribusi kepada keberhasilan kelompok.

Prosedur pembelajaran kooperatif pada prinsipnya terdiri atas 4 tahap, yaitu (1) penjelasan materi; (2) belajar dalam kelompok; (3) penilaian; dan (4) pengakuan tim (Sanjaya, 2013). Tahap penjelasan materi berisi proses penyampaian pokok materi pelajaran sebelum mahasiswa belajar dalam kelompok. Tujuan utama dari tahap ini adalah pemberian pemahaman mahasiswa terhadap pokok materi pelajaran. Dalam tahap ini, dosen memberikan gambaran tentang materi pelajaran yang harus dikuasai yang selanjutnya siswa akan memperdalam materi dalam kelompok. Pada tahap ini, dosen dapat menggunakan metode ceramah, curah pendapat, dan tanya jawab, bahkan jika perlu dosen dapat menggunakan demonstrasi. Untuk dapat menarik minat dan perhatian mahasiswa, dosen dapat menggunakan media pembelajaran.

Setelah dosen menjelaskan gambaran umum tentang pokok-pokok materi, selanjutnya mahasiswa diminta untuk belajar pada kelompok masing-masing yang telah dibentuk sebelumnya. Dalam pembelajaran ini, kelompok dibuat secara heterogen artinya kelompok dibentuk berdasarkan perbedaan-perbedaan setiap anggotanya, baik perbedaan gender, latar belakang agama, sosial ekonomi, dan etnik serta perbedaan kemampuan akademik. Lie (2005) dalam Sanjaya (2013) menyatakan kemampuan akademis dalam kelompok pembelajaran biasanya terdiri dari satu orang berkemampuan akademis tinggi, dua orang dengan kemampuan sedang, dan satu lainnya dari kelompok kemampuan akademis kurang. Alasan lebih disukainya pengelompokkan heterogen adalah (1) kelompok ini memberikan kesempatan untuk saling mengejar dan mendukung, (2) kelompok ini meningkatkan relasi, interaksi antar ras, agama, etnis, gender, dan (3) kelompok heterogen memudahkan pengelolaan kelas karena dengan adanya satu orang yang berkemampuan akademis tinggi, dosen mendapatkan satu asisten untuk setiap tiga orang. Keterlibatan mahasiswa dalam pembelajaran secara tim, mendorong mahasiswa untuk melakukan tukar-menukar informasi dan pendapat, mendiskusikan permasalahan secara bersama, membandingkan jawaban mereka, dan mengoreksi hal-hal yang kurang tepat.

Penilaian dalam pembelajaran kooperatif bisa dilakukan dengan tes atau kuis yang dilakukan secara individu atau kelompok. Tes individu nantinya akan memberikan informasi kemampuan setiap mahasiswa dan tes kelompok yang memberikan informasi kemampuan setiap kelompok. Hasil akhir, kedua penilaian ini digabung. Selain itu, pengakuan terhadap tim juga diperlukan. Pengakuan tim (team recognition) adalah penetapan tim yang dianggap paling menonjol atau tim paling berprestasi untuk kemudian diberikan penghargaan atau hadiah. Pengakuan dan pemberian penghargaan tersebut diharapkan dapat memotivasi tim untuk terus berprestasi dan membangkitkan motivasi tim lain untuk lebih mampu meningkatkan prestasi mereka.

Peningkatan kompetensi melalui kerjasama tim dapat dilakukan dengan cara menggunakan metode pembelajaran kooperatif. Namun, faktor motivasi belajar juga perlu diperhatikan dalam upaya peningkatan kompetensi menyusun laporan keuangan. Pembelajaran harus didesain agar mahasiswa tertarik dan termotivasi untuk belajar. Gamifikasi merupakan salah satu pendekatan yang dapat digunakan untuk meningkatkan motivasi belajar mahasiswa. Gamifikasi diterjemahkan sebagai pemanfaatan mekanika berbasis permainan, estetika, dan cara berpikir berbasis permainan untuk menggugah ketertarikan, motivasi beraksi, mempromosikan pembelajaran, dan menyelesaikan perrmasalahan (Kapp, 2012). Gamifikasi digunakan untuk memunculkan ketertarikan seseorang dan memotivasi seseorang untuk 
menyelesaikan suatu masalah. Cara berpikir diubah bahwa permasalahan dapat diselesaikan layaknya menyelesaikan semua tantangan yang ada dalam permainan. Gamifikasi berbeda dengan permainan atau game. Permainan merupakan sebuah sistem "abstracted reality" (kenyataan yang diubah kedalam bentuk abstrak) yang mengarahkan para pemain game dengan menggunakan aturan, interaktivitas, dan umpan balik. Di lain pihak, gamifikasi adalah aplikasi dinamis berbasis permainan dalam rangka mengedukasi.

Gamifikasi dapat digunakan dalam pembelajaran dalam rangka untuk membuat pembelajaran lebih menarik, dan terdiri dari 8 elemen, yaitu aturan, tujuan, umpan balik dan hadiah, penyelesaian masalah, cerita, pemain, lingkungan yang aman, serta tantangan dan penguasaan (Moncada \& Moncada, 2014). Karakteristik dari aktivitas gamifikasi yang didesain dengan baik adalah (Moncada \& Moncada, 2014), yaitu: (1) Mengandung tujuan pembelajaran dan hasil belajar yang jelas; (2) Mengidentifikasi kemampuan prasyarat yang diperlukan untuk aktivitas; (3) Menawarkan tantangan dan penguasaan melalui kemenangan; (4) Memperbolehkan adanya kegagalan dalam percobaan; (5) Mempergunakan skema warna yang menyenangkan; (6) Memakai tata letak yang lega (tidak penuh sesak); (7) Mengandung instruksi yang jelas dan lengkap; (8) Aturan permainan yang sederhana dan mudah dimengerti; (9) Memberikan umpan balik yang relevan dan hadiah kepada peserta; (10) Mengandung isi yang akurat dan relevan; (11) Menggalakkan keikutsertaan melalui interaktivitas.

Penerapan metode pembelajaran kooperatif berbasis gamifikasi akuntansi diharapkan dapat meningkatkan kompetensi mahasiswa dalam penyusunan laporan keuangan. Namun, penerapan ini harus diuji keefektifannya dalam meningkatkan kompetensi mahasiswa. Oleh sebab itu, diperlukan Penelitian Tindakan Kelas (PTK) untuk mengetahui keefektifan penerapan metode pembelajaran kooperatif berbasis gamifikasi tersebut. Dave Ebbutt (1985) dalam Hopkins yang diterjemahkan oleh Fawarid (2011) menyatakan bahwa penelitian tindakan merupakan studi sistematis yang dilaksanakan oleh sekelompok partisipan untuk meningkatkan praktik pendidikan dengan tindakan-tindakan praktis mereka sendiri dan refleksi mereka terhadap pengaruh dari tindakan itu sendiri. Penelitian ini termasuk dalam PTK Eksperimental yaituPTK yang diselenggarakan dengan berupaya menerapkan berbagai teknik atau strategi secara efektif dan efisien di dalam suatu kegiatan belajar mengajar (Chein, 1990). Dalam penelitian ini penerapan teknik yang digunakan adalah penerapan pembelajaran kooperatif berbasis gamifikasi akuntansi dalam pembelajaran penyusunan laporan keuangan. Prosedur yang digunakan adalah adopsi dan modifikasi proses penelitian tindakan metode Kemmis dan Taggart (1988). Berikut ini merupakan diagram alur desain Penelitian Tindakan Kelas (PTK) metode Kemmis dan Taggart (1988).

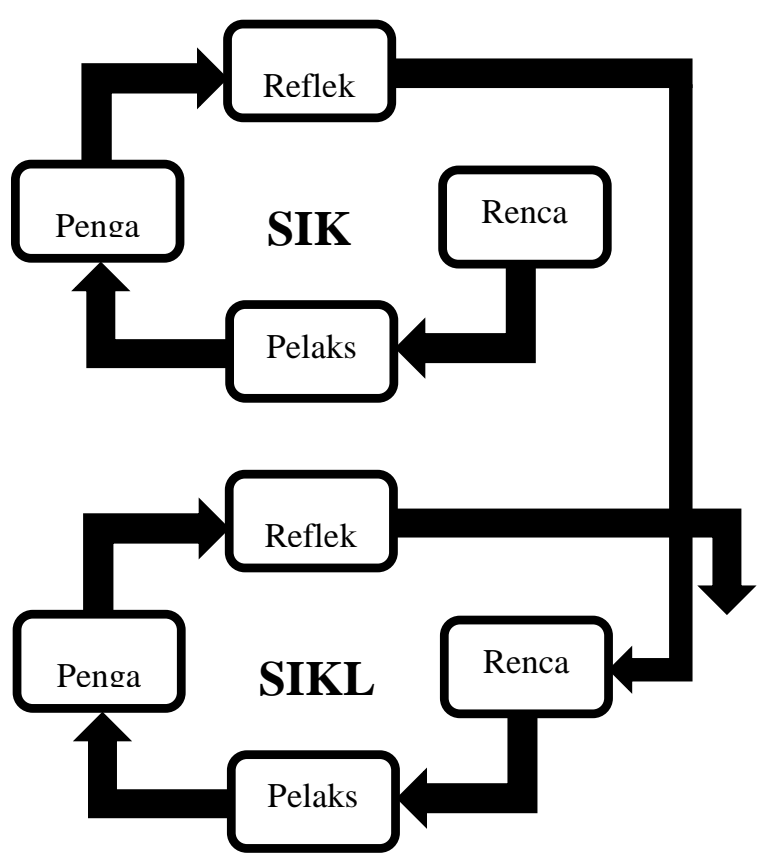

Gambar 1. Diagram Alur Desain PTK
Metode Kemmis dan Taggart (1988) 
Berdasarkan kajian literatur dan penelitian yang relevan, pertanyaan penelitian yang diajukan dalam penelitian ini, yaitu:

1. Bagaimana keefektifan penerapan pembelajaran kooperatif berbasis gamifikasi akuntansi pada kompetensi untuk meningkatkan kemampuan mahasiswa non-akuntansi dalam menyusun laporan keuangan?

2. Apakah terdapat perbedaan kemampuan mahasiswa nonakuntansi pada kelas tindakan dan kelas kontrol dalam menyusun laporan keuangan?

\section{METODE PENELITIAN Jenis Penelitian}

Penelitian ini termasuk dalam Penelitian Tindakan Kelas (PTK) Eksperimental yaituPTK yang diselenggarakan dengan berupaya menerapkan berbagai teknik atau strategi secara efektif dan efisien di dalam suatu kegiatan belajar mengajar (Chein, 1990). Dalam penelitian ini penerapan teknik yang digunakan adalah penerapan pembelajaran kooperatif berbasis gamifikasi akuntansi dalam pembelajaran penyusunan laporan keuangan. Prosedur yang digunakan adalah adopsi dan modifikasi proses penelitian tindakan metode Kemmis dan Taggart (1988), dengan melakukan 2 siklus untuk menyelesaikan permasalahan kemampuan mahasiswa dalam menyusun laporan keuangan.

\section{Subjek dan Objek Penelitian}

Subjek penelitian ini adalah mahasiswa Program Studi D3 Manajemen Pemasaran FE UNY. Subjek penelitian pada kelas tindakan berjumlah 23 mahasiswa, sedangkan jumlah mahasiswa untuk kelas kontrol berjumlah 24 mahasiswa. Objek penelitian ini adalah kemampuan mahasiswa dalam menyusun laporan keuangan yang hendak ditingkatkan melalui penerapan pembelajaran kooperatif berbasis gamifikasi akuntansi.

\section{Tempat dan Waktu Penelitian}

Penelitian ini dilakukan di Program Studi D3 Manajemen Pemasaran. Penelitian dilakukan selama 5 bulan dengan jumlah tindakan sebanyak 5 (lima) kali pertemuan dengan durasi setiap pertemuan selama 100 menit. Pertemuan untuk kelas tindakan diselenggarakan setelah kelas kontrol.

\section{Prosedur Penelitian}

Penelitian ini dilaksanakan dalam dua siklus yang meliputi perencanaan, pelaksanaan, pengamatan, dan refleksi pada setiap siklusnya. Adapun prosedur pelaksanaannya adalah sebagai berikut:

1. Siklus I

a. Perencanaan Tindakan

Perencanaan tindakan diawali dengan membuat Satuan Acara Pengajaran (SAP) untuk pokok bahasan materi Penyusunan Laporan Keuangan dengan metode pembelajaraan kooperatif. Pada tahap ini disusun pula soal pretest dan posttest untuk mengetahui peningkatan kemampuanmahasiswa. Selain itu, pada tahap ini dirancang aktivitas gamifikasi yang akan digunakan dan telah disesuaikan karakteristiknya dengan desain Moncada \& Moncada (2014). Pada tahap ini pula disiapkan lembar pengamatan, pedoman pengamatan, dan format catatan lapangan.

b. Pelaksanaan Tindakan

Setelah tahap perencanaan tindakan telah selesai dan matang, langkah selanjutnya yaitu melaksanakan rencana tersebut di kelas dengan berpedoman pada Satuan Acara Pengajaran (SAP) yang telah disusun sebelumnya. Pada tahap ini diawali dengan pemberian pretest bagi mahasiswa untuk mengetahui kemampuan awal mahasiswa tentang materi penyusunan laporan keuangan. Setelah mahasiswa mengerjakan pretest selanjutnya dosen sebagai 
pengajar melaksanakan tindakan berdasarkan SAP yang telah disusun, sedangkan observer melakukan penelitian terhadap segala kegiatan yang dilakukan mahasiswa selama proses pembelajaran dengan menggunakan pembelajaran kooperatif berbasis gamifikasi. Pelaksanaan ini bersifat fleksibel atau berubah-ubah sesuai dengan situasi dan kondisi yang terjadi di lapangan.Pada akhir pelaksanaan tindakan, mahasiswa diberikan soal posttest untuk mengetahui kemampuan mahasiswa dalam menyusun laporan keuangan.

c. Pengamatan

Kegiatan pengamatan dilakukan bersamaan dengan pelaksanaan tindakan menggunakan lembar pengamatan dan mencatat proses pembelajaran yang berlangsung dalam catatan lapangan. Selama dosen melaksanakan pembelajaran, observer melakukan pengamatan terhadap kegiatan pembelajaran kooperatif berbasis gamifikasi akuntansi dan mendokumetasikan kegiatan pembelajaran tersebut.

d. Refleksi

Proses refleksi dilakukan dengan diskusi antara peneliti dengan dua observer mengenai pelaksanaan dan pengamatan rangkaian pembelajaran. Berdasarkan catatan lapangan dan dokumentasi, dilakukan evaluasi terhadap pelaksanaan pembelajaran. Tahap refleksi ini dimaksudkan untuk mengkaji secara menyeluruh tindakan yang telah dilakukan berdasarkan data yang telah terkumpul. Pada tahap ini dilakukan pengolahan skor hasil pretest dan posttest untuk mengetahui apakah mahasiswa mengalami peningkatan kemampuan dalam penyusunan laporan keuangan. Berdasarkan hasil posttest pada siklus I, sudah terdapat peningkatan, namun ada mahasiswa yang belum mencapai tingkat keberhasilan tindakan yang telah ditetapkan. Langkah selanjutnya yaitu mengidentifikasi permasalahan yang muncul selama proses pembelajaran dan menyusun pemecahan atas masalah-masalah yang muncul agar dapat dibuat rencana perbaikan pada siklus II.

2. Siklus II

a. Perencanaan Tindakan

Perencanaan tindakan pada siklus II ini diawali dengan membuat Satuan Acara Pengajaran (SAP) untuk pokok bahasan materi Penyusunan Laporan Keuangan dengan metodepembelajaraan kooperatif. SAP yang disusun didasarkan pada hasil refleksi siklus I. Aktivitas gamifikasi yang disusun juga disesuaikan dengan refleksi pada siklus I.

b. Pelaksanaan Tindakan

Setelah tahap perencanaan tindakan telah selesai dan matang, langkah selanjutnya yaitu melaksanakan rencana tersebut di kelas dengan berpedoman pada Satuan Acara Pengajaran (SAP) yang telah disusun sebelumnya. Dosen sebagai pengajar melaksanakan tindakan berdasarkan SAP yang telah disusun, sedangkan observer melakukan penelitian terhadap segala kegiatan yang dilakukan mahasiswa selama proses pembelajaran dengan menggunakan pembelajaran kooperatif berbasis gamifikasi. Pelaksanaan ini bersifat fleksibel atau berubah-ubah sesuai dengan situasi dan kondisi yang terjadi di lapangan. Pada akhir pelaksanaan tindakan, mahasiswa kembali diberikan soal posttest untuk mengetahui peningkatan kemampuan mahasiswa dalam menyusun laporan keuangan.

c. Pengamatan

Tahap pengamatan dilakukan saat pembelajaran berlangsung, sehingga tahap ini berjalan bersamaan dengan 
tahap pelaksanaan. Kegiatan yang dilakukan pada tahap ini adalah melakukan pengamatan dan mencatat semua hal yang terjadi selama pelaksanaan tindakan berlangsung seperti kegiatan pengkondisian kelas, kegiatan mahasiswa saat mengikuti berbagai aktivitas dalam pembelajaran, pembagian kelompok, ativitas gamifikasi, diskusi, penarikan kesimpulan sampai dengan posttest.

d. Refleksi

Tahap refleksi ini bertujuan untuk mengkaji secara menyeluruh tindakan yang telah dilakukan berdasarkan data yang telah terkumpul baik dari siklus I maupun siklus II. Refleksi pada siklus II dilakukan setelah pembelajaran dilakukan. Refleksi siklus II digunakan untuk mengetahui apakah skor posttest kemampuan menyusun laporan keuangan dibandingkan hasil pretest dan posttest I telah mengalami peningkatan dan mencapai kriteria minimal. Skor diketahui melalui analisis data berdasarkan hasil pengamatan dan tes. Penelitian tindakan ini dihentikan pada siklus II karena skor rata-rata kemampuan mahasiswa dalam menyusun laporan keuangan sudah mencapai kriteria minimal.

\section{Teknik Pengambilan Data}

1. Pengamatan

Pengamatan yang dilakukan merupakan jenis pengamatan partisipatif. Pengamatan partisipatif berarti bahwa pengamat harus melibatkan diri atau ikut serta dalam kegiatan yang dilaksanakan oleh individu atau kelompok yang diamati (Sudjana, 2012). Pedoman pengamatan digunakan untuk menjaring data dalam proses belajar mengajar. Peneliti akan lebih mudah mengamati aktivitas dosen dan mahasiswa bila sudah disiapkan pedoman pengamatannya (Aqib et al, 2008). Pedoman pengamatan merupakan merupakan pedoman bagi observer untuk mengamati hal-hal yang akan diamati. Dalam penelitian ini, pedoman pengamatan diisi untuk mengidentifikasi berbagai permasalahan yang muncul pada saat pelaksanaan pembelajaran dengan metode pembelajaran kooperatif berbasis gamifikasi akuntansi berjalan.

2. Catatan Lapangan

Sumber informasi yang sangat penting dalam penelitian tindakan kelas adalah catatan lapangan yang dibuat oleh peneliti yang melakukan pengamatan (Wiriaatmadja, 2006). Catatan lapangan digunakan untuk mendeskripsikan situasi dan kondisi saat pembelajaran di kelas. Catatan lapangan ini digunakan untuk mengumpulkan data tentang situasi dan kondisi saat proses pelaksanaan tindakan kelas, seperti proses pembelajaran, pelaksanaan aktivitas gamifikasi, maupun interaksi dosen dengan mahasiswa interaksi mahasiswa dengan mahasiswa yang lain.

3. Dokumentasi

Dokumentasi dalam penelitian ini merupakan teknik pengumpulan data menggunakan dokumen tertulis berupa administrasi dosen berupa Rencana Pembelajaran Semester (RPS), Satuan Acara Pengajaran (SAP), dan data latar belakang pendidikan mahasiswa serta nilai pretest yang digunakan sebagai dasar pembentukan kelompok dan tolok ukur awal kemampuan mahasiswa di dalam pembelajaran akuntansi kompetensi menyusun laporan keuangan.

4. Tes

Teknik pengumpulan data yang lain yaitu tes. Tes merupakan instrumen untuk mengumpulkan data prestasi belajar peserta didik, baik melalui tes lisan, tertulis, maupun perbuatan (Mulyasa, 2009). Tes sebagai alat pengukuran dalam evaluasi memberikan data kuantitatif dalam bentuk nilai atau skor. Penelitian ini menggunakan pretest dan posttestI serta posttest II untuk mengetahui peningkatan 
kemampuan mahasiswa. Soal pretest dan posttest disesuaikan dengan indikator yang telah ditentukan dalam RPS dan SAP.

\section{Teknik Analisis Data}

Teknik analisis yang digunakan dalam penelitian ini adalah teknik analisis data deskriptif kuantitatif untuk menganalisis peningkatan kemampuan mahasiswa dalam menyusun laporan keuangan berdasarkan hasil pretest, posttest I, dan posttest II. Data yang diperoleh dari hasil observasi dianalisis untuk mengetahui persentase skor pemahaman akuntansi sebagai berikut (Sugiyono, 2009):

1. Menentukan kriteria pemberian skor terhadap masing-masing indikator kemampuan menyusun laporan keuangan.

2. Menjumlahkan skor untuk masing-masing indikator kemampuan menyusun laporan keuanganyang diamati.

3. Menghitung skor kemampuan menyusun laporan keuangan pada setiap indikator yang diamati dengan rumus:

$$
\begin{aligned}
& \text { Skor Tes } \\
& \text { Menyusun } \\
& \text { Nilai }=\frac{\begin{array}{c}
\text { Laporan } \\
\text { Keuangan }
\end{array}}{\text { Skor }} \times 100 \%
\end{aligned}
$$

Rumus di atas merupakan rumus untuk menghitung nilai setiap mahasiswa secara individu. Rumus yang digunakan untuk peningkatan kemampuan mahasiswa dalam menyusun laporan keuangan adalah sebagai berikut:

$$
\text { Nilai Rata-rata }=\frac{\begin{array}{c}
\text { Jumlah Nilai } \\
\text { Seluruh } \\
\text { Mahasiswa }
\end{array}}{\begin{array}{c}
\text { Jumlah } \\
\text { Mahasiswa }
\end{array}}
$$

Analisis data lain yang digunakan yaitu uji beda. Uji beda digunakan untuk mengetahui perbedaan antara nilai tes kemampuan menyusun laporan keuangan pada kelas tindakan dan kelas kontrol serta nilai tes mahasiswa kelas tindakan sebelum dan sesudah penerapan tindakan. Hal ini bertujuan untuk mengetahui keefektifan penggunaan metode pembelajaran kooperatif berbasis gamifikasi untuk meningkatkan kemampuan mahasiswa dalam menyusun laporan keuangan.

\section{Indikator Keberhasilan Tindakan}

Indikator keberhasilan tindakan ini adalah apabila minimal $75 \%$ dari jumlah mahasiswa mendapat nilai tes kemampuan menyusun laporan keuangan $\geq 75$. Selain itu, keberhasilan tindakan juga dilihat pada ada atau tidaknya perbedaan kemampuan pada kelas tindakan setelah adanya tindakan. Perbedaan peningkatan yang signifikan menunjukkan keberhasilan tindakan yang diberikan.

\section{HASIL PENELITIAN DAN PEMBAHASAN}

Sebelum siklus dalam Penelitian Tindakan Kelas (PTK) ini dilakukan pengelompokkan untuk menentukan mahasiswa yang akan masuk ke dalam kelas tindakan dan kelas kontrol. Subjek penelitian ini adalah mahasiswa baru Program Studi D3 Manajemen Pemasaran FE UNY sejumlah 46 mahasiswa. Mahasiswa dikelompokkan menjadi dua kelas secara acak. Kelas tindakan berisi 23 mahasiswa, kelas kontrol juga berisi 23 mahasiswa. Perkuliahan untuk dua kelas ini diselenggarakan pada hari yang sama namun waktu yang berbeda. Setelah terbagi ke dalam dua kelas, mahasiswa diberi pretest untuk mengukur kemampuan awal mahasiswa dan untuk mengetahui bahwa kelas tindakan dan kelas kontrol tidak memiliki perbedaan kemampuan. Berikut ini merupakan hasil pretest pada kelas tindakan (KK) dan kelas kontrol (KK) dan uji Independent Sample T-Test. 
Tabel 1. Hasil Pretest

\begin{tabular}{|l|r|l|r|}
\hline \multicolumn{2}{|c|}{$\begin{array}{c}\text { Kelas Tindakan } \\
\text { (KT) }\end{array}$} & \multicolumn{2}{c|}{$\begin{array}{c}\text { Kelas Kontrol } \\
\text { (KK) }\end{array}$} \\
\hline Nama & Nilai & Nama & Nilai \\
\hline WR & 45 & ANS & 55 \\
\hline RD & 30 & TRN & 40 \\
\hline IV & 75 & ILY & 60 \\
\hline GT & 45 & SVR & 50 \\
\hline SQ & 45 & DIN & 65 \\
\hline RQ & 50 & UMM & 50 \\
\hline PP & 60 & DSN & 60 \\
\hline NR & 55 & SLL & 55 \\
\hline WC & 55 & BYU & 70 \\
\hline DV & 80 & GLG & 50 \\
\hline NF & 70 & EGA & 75 \\
\hline
\end{tabular}

\begin{tabular}{|l|r|l|r|}
\hline EL & 65 & ATF & 55 \\
\hline HD & 45 & FLD & 85 \\
\hline AJ & 55 & PRD & 65 \\
\hline NK & 80 & AGT & 70 \\
\hline FT & 60 & YNA & 45 \\
\hline AM & 35 & DLA & 40 \\
\hline UW & 65 & HRK & 40 \\
\hline AG & 60 & AZZ & 55 \\
\hline ID & 75 & RFA & 75 \\
\hline AT & 60 & DWI & 50 \\
\hline KT & 55 & RZA & 85 \\
\hline HS & 50 & AFN & 35 \\
\hline Rata-rata & 57,17 & Rata-rata & 57,82 \\
\hline
\end{tabular}

\section{Tabel 2. Uji Independent Sample T-Test}

\begin{tabular}{|c|c|c|c|c|c|c|c|c|c|c|}
\hline & \multicolumn{2}{|c|}{$\begin{array}{c}\text { Levene's } \\
\text { Test for } \\
\text { Equality of } \\
\text { Variances } \\
\end{array}$} & \multicolumn{7}{|c|}{ t-test for Equality of Means } \\
\hline & & \multirow[t]{2}{*}{$\mathbf{F}$} & \multirow[t]{2}{*}{ Sig. } & \multirow[t]{2}{*}{$\mathbf{t}$} & \multirow[t]{2}{*}{ df } & \multirow[t]{2}{*}{$\begin{array}{l}\text { Sig. (2- } \\
\text { tailed) }\end{array}$} & \multirow[t]{2}{*}{$\begin{array}{c}\text { Mean } \\
\text { Difference }\end{array}$} & \multirow[t]{2}{*}{$\begin{array}{l}\text { Std. Error } \\
\text { Difference }\end{array}$} & \multicolumn{2}{|c|}{$\begin{array}{l}\text { 95\% Confidence } \\
\text { Interval of the } \\
\text { Difference }\end{array}$} \\
\hline & & & & & & & & & Lower & Upper \\
\hline \multirow[b]{2}{*}{ Nilai } & \begin{tabular}{|c} 
Equal \\
variances \\
assumed
\end{tabular} &, 157 & ,694 &,- 161 & 44 &, 873 &,- 652 & 4,058 & $-8,831$ & 7,526 \\
\hline & $\begin{array}{c}\text { Equal } \\
\text { variances } \\
\text { not } \\
\text { assumed }\end{array}$ & & &,- 161 & 43,872 & ,873 &,- 652 & 4,058 & $-8,831$ & 7,527 \\
\hline
\end{tabular}

Berdasarkan tabel 2 dapat diketahui bahwa nilai atau skor rata-rata tes kelas tindakan sebesar 57,17 dan kelas kontrol sebesar 57,82 masih di bawah kriteria yang ditetapkan yaitu 75. Selain itu, mahasiswa yang mampu memenuhi kriteria minimal pada kelas tindakan hanya 4 mahasiswa atau sebesar $17,39 \%$. Begitu pula dengan kelas kontrol, baru sedikit mahasiswa yang mampu memenuhi kriteria minimal yaitu sebanyak 4 mahasiswa atau sebesar 17,39\%. Berdasarkan tabel 2 hasil uji beda Independent Sample T-Test diperoleh bahwa nilai Sig.(2-tailed) sebesar 0,873 > 0,05 . Dengan demikian dapat disimpulkan bahwa tidak terdapat perbedaan kemampuan antara kelas tindakan dan kelas kontrol.

Langkah selanjutnya setelah diketahui tidak terdapat perbedaan kemampuan antara kelas tindakan dan kelas kontrol adalah menerapkan tindakan pada kelas tindakan yaitu pembelajaran dengan metode pembelajaran kooperatif berbasis gamifikasi akuntansi pada kompetensi menyusun laporan keuangan. Materi yang dibahas adalah neraca lajur, laporan laba rugi, laporan perubahan ekuitas, dan laporan posisi keuangan. Pada awal pertemuan, dosen membentuk tim sejumlah 
6 tim dengan anggota 3-4 mahasiswa. Pembelajaran dilakukan dengan melakukan aktivitas gamifikasi dengan permainan yang telah disiapkan oleh dosen. Dosen hanya berperan sebagai fasilitator dan motivator. Setelah pembelajaran selesai dan materi tuntas dipelajari oleh mahasiswa melalui aktivitas gamifikasi dilakukan posttest I untuk mengukur kemampuan menyusun laporan keuangan. Posttest I juga diberikan pada kelas kontrol yang menggunakan metode ceramah, latihan, dan tugas. Berikut ini merupakan hasil posttest I kelas tindakan dan kelas kontrol.

Tabel 3. Hasil Posttest I

\begin{tabular}{|l|r|l|r|}
\hline \multicolumn{2}{|c|}{$\begin{array}{c}\text { Kelas Tindakan } \\
\text { (KT) }\end{array}$} & \multicolumn{2}{c|}{$\begin{array}{c}\text { Kelas Kontrol } \\
\text { (KK) }\end{array}$} \\
\hline WR & Nilai & \multicolumn{1}{|c|}{ Nama } & \multicolumn{1}{c|}{ Nilai } \\
\hline RD & 65 & ANS & 65 \\
\hline IV & 65 & TRN & 55 \\
\hline GT & 85 & ILY & 80 \\
\hline SQ & 60 & SVR & 70 \\
\hline RQ & 70 & DIN & 85 \\
\hline PP & 75 & UMM & 70 \\
\hline NR & 70 & DSN & 75 \\
\hline WC & 65 & SLL & 65 \\
\hline DV & 65 & BYU & 80 \\
\hline NF & 95 & GLG & 60 \\
\hline EL & 85 & EGA & 80 \\
\hline HD & 75 & ATF & 65 \\
\hline AJ & 60 & FLD & 85 \\
\hline NK & 65 & PRD & 70 \\
\hline FT & 90 & AGT & 70 \\
\hline AM & 80 & YNA & 60 \\
\hline UW & 60 & DLA & 60 \\
\hline AG & 80 & HRK & 55 \\
\hline ID & 75 & AZZ & 65 \\
\hline AT & 85 & RFA & 80 \\
\hline KT & 80 & DWI & 60 \\
\hline HS & 65 & RZA & 90 \\
\hline Rata-rata & 63,04 & AFN & 50 \\
\hline & & & 69,35 \\
\hline
\end{tabular}

Berdasarkan tabel 3 hasil posttest I di kelas tindakan dapat diketahui bahwa rata-rata tes untuk mengukur kemampuan mahasiswa dalam menyusun laporan keuangan belum mencapai kriteria yang ditetapkan, yaitu sebesar 73,04 $<75$. Terdapat 12 mahasiswa atau sebesar $52,17 \%$ yang belum mencapai kriteria minimal. Di kelas lain, yaitu kelas kontrol berdasarkan hasil posttest I dapat diketahui bahwa rata-rata tes untuk mengukur kemampuan mahasiswa dalam menyusun laporan keuangan juga belum mencapai kriteria yang ditetapkan, yaitu sebesar $69,35<75$. Terdapat 15 mahasiswa atau sebesar $65,22 \%$ yang belum mencapai kriteria minimal. Berdasarkan hasil posttest I diketahui bahwa tindakan yang diberikan pada siklus I belum berhasil meningkatkan kemampuan sampai dengan kriteria minimal. Oleh sebab itu, siklus akan dilanjutkan ke siklus II. Begitu pula dengan kelas tindakan, materi tentang penyusunan laporan keuangan kembali dijelaskan.

Siklus II pada penelitian ini memuat materi yang sama dengan siklus I. Materi yang dibahas adalah neraca lajur, laporan laba rugi, laporan perubahan ekuitas, dan laporan posisi keuangan. Pada awal pertemuan, dosen kembali membentuk tim sejumlah 6 tim dengan anggota 3-4 mahasiswa. Pembelajaran dilakukan dengan melakukan aktivitas gamifikasi dengan permainan yang telah disiapkan oleh dosen. Dosen hanya berperan sebagai fasilitator dan motivator. Setelah pembelajaran selesai dan materi tuntas dipelajari oleh mahasiswa melalui aktivitas gamifikasi dilakukan posttest II untuk mengukur kemampuan menyusun laporan keuangan. Posttest II juga diberikan pada kelas kontrol yang menggunakan metode ceramah, latihan, dan tugas. Berikut ini disajikan hasil posttest II kelas tindakan dan kelas kontrol.

Tabel 4. Hasil Posttest II

\begin{tabular}{|l|r|l|r|}
\hline \multicolumn{2}{|c|}{$\begin{array}{c}\text { Kelas Tindakan } \\
(\text { KT) }\end{array}$} & \multicolumn{2}{c|}{$\begin{array}{c}\text { Kelas Kontrol } \\
\text { (KK) }\end{array}$} \\
\hline Nama & Nilai & \multicolumn{1}{c|}{ Nama } & \multicolumn{1}{c|}{ Nilai } \\
\hline WR & 80 & ANS & 80 \\
\hline RD & 85 & TRN & 65 \\
\hline IV & 90 & ILY & 90 \\
\hline GT & 85 & SVR & 70 \\
\hline SQ & 85 & DIN & 95 \\
\hline
\end{tabular}




\begin{tabular}{|l|r|l|r|}
\hline RQ & 90 & UMM & 85 \\
\hline PP & 85 & DSN & 90 \\
\hline NR & 85 & SLL & 85 \\
\hline WC & 80 & BYU & 90 \\
\hline DV & 100 & GLG & 70 \\
\hline NF & 100 & EGA & 85 \\
\hline EL & 85 & ATF & 70 \\
\hline HD & 70 & FLD & 90 \\
\hline AJ & 70 & PRD & 70 \\
\hline NK & 100 & AGT & 85 \\
\hline FT & 100 & YNA & 85 \\
\hline AM & 70 & DLA & 85 \\
\hline UW & 100 & HRK & 60 \\
\hline AG & 100 & AZZ & 65 \\
\hline ID & 100 & RFA & 90 \\
\hline AT & 100 & DWI & 80 \\
\hline KT & 85 & RZA & 95 \\
\hline HS & 70 & AFN & 70 \\
\hline Rata-rata & 87,60 & Rata-rata & 80,43 \\
\hline
\end{tabular}

Berdasarkan tabel 4 hasil posttest II di kelas tindakan dapat diketahui bahwa rata-rata tes untuk mengukur kemampuan mahasiswa dalam menyusun laporan keuangan sudah mencapai kriteria yang ditetapkan, yaitu sebesar 87,60 > 75. Terdapat 4 mahasiswa atau sebesar $17,39 \%$ yang masih belum mencapai kriteria minimal. Di kelas lain, yaitu kelas kontrol berdasarkan hasil posttest II dapat diketahui bahwa rata-rata tes untuk mengukur kemampuan mahasiswa dalam menyusun laporan keuangan juga sudah mencapai kriteria yang ditetapkan, yaitu sebesar 80,43> 75 . Terdapat 8 mahasiswa atau sebesar $34,78 \%$ yang belum mencapai kriteria minimal.

Berdasarkan hasil posttest II dapat diketahui bahwa pemberian tindakan berhasil meningkatkan kemampuan mahasiswa dalam menyusun laporan keuangan. Rata-rata nilai atau sor tes yang diperoleh kelas tindakan menunjukkan peningkatan, yaitu 57,17; 73,04; dan 87,60. Selain itu, jumlah mahasiswa yang mampu memenuhi kriteria minimal juga semakin meningkat yaitu pada saat pretest hanya sebanyak 4 (17,39\%) mahasiswa, posttest I sebanyak $11 \quad(47,83 \%)$ mahasiswa, sedangkan posttest II mencapai 19 $(82,61 \%)$ mahasiswa. Hal ini menunjukkan bahwa penerapan pembelajaran kooperatif berbasis gamifikasi akuntansi berhasil meningkatkan kemampuan mahasiswa pada kompetensi menyusun laporan keuangan. Keefektifan penerapan metode ini diuji secara statistik dengan uji beda Independent Sampel T-Test untuk membedakan kemampuan mahasiswa pada kelas tindakan dan kelas kontrol dan uji beda Paired Sample T-Test untuk mengetahui perbedaan peningkatan kemampuan mahasiswa pada kompetensi menyusun laporan keuangan di kelas tindakan. Berikut ini hasil uji beda Independent Sampel T-Test dan uji beda Paired Sample T-Test. 


\begin{tabular}{|c|c|c|c|c|c|c|c|c|c|c|}
\hline \multicolumn{11}{|c|}{ Tabel 5. Independent Samples T-Test } \\
\hline & & $\begin{array}{r}\text { Lev } \\
\text { Tes } \\
\text { Equa } \\
\text { Vari }\end{array}$ & $\begin{array}{l}\text { ne's } \\
\text { for } \\
\text { ty of } \\
\text { nces }\end{array}$ & \multicolumn{7}{|c|}{ t-test for Equality of Means } \\
\hline & & \multirow[t]{2}{*}{$\mathrm{F}$} & \multirow[t]{2}{*}{ Sig. } & \multirow[t]{2}{*}{$\mathrm{t}$} & \multirow[t]{2}{*}{ df } & \multirow[t]{2}{*}{$\begin{array}{l}\text { Sig. (2- } \\
\text { tailed) }\end{array}$} & \multirow[t]{2}{*}{$\begin{array}{c}\text { Mean } \\
\text { Difference }\end{array}$} & \multirow[t]{2}{*}{$\begin{array}{l}\text { Std. Error } \\
\text { Difference }\end{array}$} & \multicolumn{2}{|c|}{$\begin{array}{c}95 \% \\
\text { Confidence } \\
\text { Interval of the } \\
\text { Difference }\end{array}$} \\
\hline & & & & & & & & & Lower & Upper \\
\hline \multirow[b]{2}{*}{$\begin{array}{c}\text { Nilai } \\
2\end{array}$} & $\begin{array}{c}\text { Equal } \\
\text { variances } \\
\text { assumed }\end{array}$ & ,001 & ,981 & 2,262 & 44 & ,029 & 7,174 & 3,171 & ,782 & $\begin{array}{c}13,56 \\
5\end{array}$ \\
\hline & $\begin{array}{c}\text { Equal } \\
\text { variances } \\
\text { not } \\
\text { assumed }\end{array}$ & & & 2,262 & 43,934 & ,029 & 7,174 & 3,171 & ,782 & $\begin{array}{c}13,56 \\
6\end{array}$ \\
\hline
\end{tabular}

\begin{tabular}{|c|c|c|c|c|c|c|c|c|c|}
\hline \multicolumn{10}{|c|}{ Tabel 6. Paired Samples T-Test } \\
\hline & & \multicolumn{5}{|c|}{ Paired Differences } & \multirow{3}{*}{$\mathrm{t}$} & \multirow{3}{*}{ df } & \multirow{3}{*}{$\begin{array}{l}\text { Sig. (2- } \\
\text { tailed) }\end{array}$} \\
\hline & & \multirow[t]{2}{*}{ Mean } & \multirow{2}{*}{$\begin{array}{l}\text { Std. } \\
\text { Deviati } \\
\text { on }\end{array}$} & \multirow{2}{*}{$\begin{array}{l}\text { Std. } \\
\text { Error } \\
\text { Mean }\end{array}$} & \multicolumn{2}{|c|}{$\begin{array}{l}95 \% \text { Confidence } \\
\text { Interval of the } \\
\text { Difference }\end{array}$} & & & \\
\hline & & & & & Lower & Upper & & & \\
\hline $\begin{array}{c}\text { Pair } \\
1\end{array}$ & $\begin{array}{c}\text { Pretest_KT - } \\
\text { Posttest2_K } \\
\text { T }\end{array}$ & $-30,435$ & 10,103 & 2,107 & $-34,804$ & $-26,066$ & $-14,447$ & 22 &, 000 \\
\hline
\end{tabular}

Berdasaran tabel 5 dapat diketahui bahwa output Independent Sample T-Test diperoleh nilai Sig.(2-tailed) sebesar 0,029 $<0,05$, maka dapat dikatakan bahwa terdapat perbedaan kemampuan mahasiswa pada kompetensi menyusun laporan keuangan antara kelas tindakan dan kelas kontrol. Tabel 6 menunjukkan bahwa nilai Sig.(2-tailed) sebesar $0,000<0,05$, maka dapat dikatakan bahwa terdapat perbedaan kemampuan mahasiswa pada kompetensi menyusun laporan keuangan sebelum dan sesudah penerapan metode pembelajaraan kooperatif berbasis gamifikasi akuntansi. Berdasarkan hal-hal tersebut dapat dikatakan bahwa penerapan metode pembelajaran kooperatif berbasis gamifikasi akuntansi lebih efektif untuk meningkatkan kemampuan mahasiswa dalam menyusun laporan keuangan.

Hasil penelitian ini menunjukkan bahwa pembelajaran dengan menggunakan metode pembelajaran kooperatif berbasis gamifikasi akuntansi dapat meningkatkan kemampuan mahasiswa. Hal ini sejalan dengan pendapat yang dikemukakan oleh Hill \& Hill (1993) bahwa pembelajaran kooperatif dapat meningkatkan prestasi siswa mahasiswa, memperdalam pemahaman siswa, dan menyenangkan mahasiswa. Karli dan Yuliariatiningsih (2002) juga mengemukakan bahwa pembelajaran kooperatif dapat mengembangkan pengetahuan mahasiswa dalam suasana yang bebas dengan adanya kerjasama yang positif dengan mahasiswa yang lain. Suasana yang menyenangkan, adanya unsur kerjasama, dan pencapaian target oleh tim dapat mendorong mahasiswa untuk menikmati pembelajaran dan berprestasi lebih baik.

Pendekatan gamifikasi yang digunakan dapat menambah motivasi bagi mahasiswa untuk belajar. Mereka seolah-olah bukan 
melakukan aktivitas belajar namun aktivitas bermain. Suasana santai dan menyenangkan dapat meningkatkan motivasi dan kemudahan mahasiswa dalam belajar yang dapat berdampak pada peningkatan kemampuan mahasiswa. Hal ini sesuai dengan pendapat Kapp (2012) bahwa gamifikasi dapat meningkatkan motivasi.

\section{SIMPULAN DAN SARAN \\ Simpulan}

Berdasarkan hasil penelitian dan pembahasan dapat disimpulkan bahwa penerapan metode pembelajaran kooperatif berbasis gamifikasi dapat meningkatkan kemampuan mahasiswa dalam menyusun laporan keuangan. Selain itu, penerapan metode ini juga lebih efektif untuk meningkatkan kemampuan jika dibandingkan dengan metode ceramah dan latihan.

\section{Keterbatasan}

Pelaksanaan penelitian tindakan kelas ini memiliki keterbatasan antara lain adalah peneliti kesulitan untuk mengendalikan perilaku subjek penelitian ketika mereka berada di luar kelas. Hal ini memungkinkan adanya interaksi antara subjek di kelas tindakan dan kelas kontrol sehingga dapat dimungkinkan berpengaruh terhadap hasil tes.

\section{Saran}

Berdasarkan hasil penelitian, saran yang dapat diberikan yaitu sebaiknya dosen menggunakan metode pembelajaran kooperatif berbasis gamifikasi untuk mata kuliah yang diampu agar mahasiswa lebih termotivasi, meningkatkan kerjasama positif, dan mudah memahami materi yang dipelajari.

\section{DAFTAR PUSTAKA}

Boyas, Elise A. (2008). Using PowerPoint to Encourage Active Learning: A Tool to Enhance Student Learning in the First Accounting Course. International Journal of Information and Communication Technology Education, Volume 4, Issue 2. USA: IGI Global.

Brickner, Daniel R., Etter, Edwin R. (2008). Strategies for Promoting Active Learning in a Principles of Accounting Course. Academy of Educational Leadership Journal, Volume 12, Number 2.

Cheng, K W Kevin. (2009). The Effect of Web-Based Collaborative Learning Methods to The Accounting Course in Technical Education. College Student Journal; Volume 43, Number 3; ProQuest Education Journal pg. 755.

De Araujo, Adriana Maria Procópio; Slomski, Vilma Geni. (2013). Active Learning Methods-An Analysis of Applications and Experiences in Brazilian Accounting Teaching. Creative Education. Volume 4, Number 12B, pp. 20-27.

Deterding, Sebastian; Dixon, Dan; Khaled, Rilla; Nacke, Lennart. 2011. From Game Design Elements to Gamefulness: Defining "Gamification". MindTrek'11, September 28-30. Finland: Tampere.

Deterding, Sebastian; Dixon, Dan; Khaled, Rilla; Nacke, Lennart. 2011. Gamification: Toward a Definition. CHI, May 7-12 2011, Vancouver, BC, Canada.

DuWayne, L. Dockter. (2012). ProblemBased Learning In Accounting. American Journal of Business Education; Volume 5, Number 5.

Edmond, Tracie; Tiggeman, Theresa. (2009). Accounting Experiences in Collaborative Learning. American 
Journal of Business Education; Volume 2, Number 7; ProQuest pg. 97.

Fowler, Lou. (2006). Active Learning: An Empirical Study of The Use of Simulation Games in The Introductory Financial Accounting Class. Academy of Educational Leadership Journal; 2006; Volume 10, Number 3; ProQuest pg. 93.

Gall, J., Borg. W., \& Gall, M. (2003). Educational Research: An Introduction ( $7^{\text {th }} \quad$ ed.). Boston: Pearson Education.

Hodkiewicz, Melinda R. 2012. Snakes and Ladders - Identifying Risks to Asset Management Strategy. Third International Engineering Systems Symposium. Delft University of Technology, 18-20 June 2012.

Kapp, Karl M. 2012. The Gamification of Learning and Instruction: Gamebased Methods And Strategies For Training And Education. Pfeiffer.

Kemmis, S., McTaggart, R. 1988. The Action Research Planner (3rd ed.). Geelong, Victoria: Deakin University Press.

Laing, Gregory Kenneth. 2010. An Empirical Test of Mnemonic Devices to Improve Learning in Elementary Accounting. Journal of Education for Business, Volume 85: pp. 349-358. Australia: Taylor \& Francis Group, LLC.

Liargovas, P., \& Skandalis, K. (2008). Factor affecting firms financial performance: The Case of Greece. Athens: University of Peloponnese Press.

Miller, Craig. 2013. The Gamification of Education. Developments in Business Simulation and Experiential Learning, Volume 40.

Moncada, Susan M.; Moncada, Thomas P. 2014. Gamification of Learning in
Accounting Education. Journal of Higher Education Theory and Practice; Volume 14.

Mujiono dan Dimyati. (2006). Belajar dan Pembelajaran. Jakarta: Rineka Cipta.

Opdecam, Evelien; Everaert, Patricia. (2012). Improving Student Satisfaction in a First-Year Undergraduate Accounting Course by Team Learning. Issues in Accounting Education; Volume 27, Number 1; pp. 53-82. USA: American Accounting Association.

Reeves, Henry. (2011). Financial Statement Analysis For Small Businesses: A Resource Guide. Virginia: Small Business Development Center.

Sagala, Syaiful. (2009). Konsep dan Makna Pembelajaran untuk Membantu Memecahkan Problematika Belajar dan Mengajar. Bandung: Alfabeta.

Sagoro, E.M. (2015). Akuntansi Tanpa Stres. Yogyakarta: AB Publisher.

Salazar, Alejandra López; Soto, Ricardo Contreras; Mosqueda, Rafael Espinosa. (2012). The Impact of Financial Decisions and Strategy on Small Business Competitiveness. Global Journal of Business Research; Volume 6, Number 2.

Sudjana, Nana. (2005). Penilaian Hasil Proses Belajar Mengajar. Bandung: PT Remaja Rosdakarya.

Suprijono, Agus. (2011). Cooperative Learning. Yogyakarta: Pustaka Pelajar.

Suwardjono. (2002). Akuntansi Pengantar 1: Proses Penciptaan Data, Pendekatan Sistem. Yogyakarta: BPFE.

Warsono, Sony, dkk. 2010. Akuntansi UMKM Ternyata Mudah Dipahami dan Dipraktikkan. Yogyakarta: Asgard Chapter. 
Jurnal Pendidikan Akuntansi Indonesia, Vol. XIV, No. 2, Tahun 2016

Endra Murti Sagoro

$63-79$

Weygandt, J.J., Kieso, D.E., \& Kimmel,

P.D. (2007). Pengantar akuntansi edisi tujuh. (Terjemahan Ali Akbar Yulianto, Wasilah, \& Rangga Handika). Jakarta: Salemba Empat.

(Buku asli diterbitkan tahun 2005).

Wina Sanjaya. (2011). Strategi

Pembelajaran Berorientasi Standar

Proses Pendidikan. Jakarta: Kencana. 